\title{
The Elective and Automatic Theories of Termination in the Common Law of the Contract of
}

\section{Employment: Conundrum Resolved?}

David Cabrelli \& Rebecca Zahn*

Keywords: Employment Law, Contract of Employment, Termination of the Contract of Employment, Gunton v Richmond-upon-Thames London Borough Council, Société Générale (London Branch) v Geys

\section{A. Introduction}

Under general contractual principles, if one party commits a repudiatory breach of contract, the other party has the option either to terminate or affirm the contract: this is referred to as the 'elective' theory of termination. ${ }^{1}$ However, it has long been unclear whether the same principle of election applies in relation to a wrongful dismissal or resignation in breach of an employment contract or whether the law should prefer a theory based on automatic termination. The 'automatic' theory posits that one party's unilateral repudiatory breach operates to bring the contract of employment to an end, thus depriving the innocent party of the right of election. Both approaches had found favour in the common law at various times ${ }^{2}$ and owing to the fact that the Court of Appeal had adopted the elective theory with uncharacteristic diffidence in the most recent leading

\footnotetext{
*David Cabrelli is Senior Lecturer in Commercial Law at the University of Edinburgh. Rebecca Zahn is Lecturer in Law at the University of Stirling.

${ }^{1}$ White and Carter (Councils) Ltd. v McGregor [1962] AC 413 and Photo Production Ltd. v Securicor Transport Ltd. [1980] AC 827.

${ }^{2}$ In Gunton v Richmond-upon-Thames London Borough Council [1981] 1 Ch 448, the Court of Appeal preferred the elective approach, whereas in Sanders v Ernest A Neale Ltd [1974] ICR 565, the National Industrial Relations Court opted for the automatic theory.
} 
authority, ${ }^{3}$ the law was subject to the charge that it lacked certainty or clarity in the absence of a definitive pronouncement at the highest appellate level on the matter.

The recent decision of the Supreme Court in Société Générale (London Branch) v Geys ${ }^{4}$ handed down on $19^{\text {th }}$ December 2012 has finally resolved this question. By a majority, the Supreme Court held that the elective theory also applies in the context of a wrongful repudiation of the employment contract by express dismissal or resignation. After briefly outlining the facts of, and the reasoning applied in, the case, this note examines the significance of Geys and evaluates whether a number of related issues surrounding the breach and termination of the employment contract have been resolved. Additional matters raised by the decision will also be addressed, including the wider implications of Geys for the stability of the structural framework of the common law of the contract of employment in light of recent appellate jurisprudence.

\section{B. Facts of the case}

Mr Geys was employed by the London Branch of Société Générale ('the Bank') from February 2005 onwards as the Managing Director of its European Fixed Income Sales, Financial Institutions Division. On 29 November 2007 he was informed at a meeting that the Bank had decided to summarily dismiss him with immediate effect, but no ground for such dismissal was communicated at that time. On 18 December 2007, the Bank tendered a sum into Mr. Geys' bank account and the Bank sent Mr. Geys details of the payment, but omitted to inform him why the payment had been made. Correspondence between the Bank and Mr Geys's solicitors followed between late December 2007 and early January 2008 which sought to clarify matters. On 2nd January 2008, Mr. Geys wrote to the

\footnotetext{
${ }^{3}$ In Boyo v Lambeth London Borough Council [1994] ICR 727, 743H-744A per Ralph Gibson L, there was a begrudging acceptance that they were bound by the earlier decision in Gunton v Richmond-uponThames London Borough Council [1981] 1 Ch 448 as a matter of precedent.

${ }^{4}$ [2012] UKSC 63; [2013] 2 WLR 50.
} 
Bank to confirm that he had affirmed the contract of employment, whereupon the Bank subsequently wrote a letter to $\mathrm{Mr}$ Geys on $4^{\text {th }}$ January 2008 . This letter confirmed the termination of Mr Geys' employment contract and invoked a clause in the Bank's Staff Handbook which was incorporated into Mr. Geys' contract of employment empowering the Bank to terminate his employment with immediate effect by making a payment in lieu of notice (PILON). The terms of the employment contract dictated that Mr. Geys was deemed to have received that letter on $6^{\text {th }}$ January 2008.

The dispute centred on the exact date of termination of the employment contract and the amount due to Mr Geys as a result of the termination. In the Court of Appeal, Lord Justice Rimer followed the precedent set in Gunton v Richmond-upon-Thames London Borough Council'5and confirmed in Boyo v Lambeth London Borough Council' by holding that 'an unaccepted repudiation of a contract of employment does not automatically terminate it. ${ }^{7}$ He did however give the Bank "permission to appeal on that ground, solely to enable it to keep open the possibility of an appeal to the Supreme Court to re-consider this area of the law. ${ }^{8}$ The Supreme Court considered the issue at a hearing on $17^{\text {th }}$ and $18^{\text {th }}$ October 2012. The parties' submissions to the Supreme Court for the most part focussed on the proper construction of the provisions contained in Mr Geys' employment contract and the correct method of operation of the PILON clause which the Bank had invoked; neither of which will be discussed in this note. In addition, both parties set out their views on the advantages and disadvantages of the elective and automatic theories of termination of the employment contract which are addressed in greater detail below. Counsel for the Bank suggested that the automatic theory ought to be applied in the case of 'wrongful dismissals and resignations which are 'express

\footnotetext{
${ }^{5}[1981] 1$ Ch 448.

${ }^{6}[1994]$ ICR 727.

${ }^{7}$ [2011] EWCA Civ 307; [2011] I.R.L.R. 482, 486 at [17].

8 ibid 487 at [18].
} 
and immediate' or 'outright'. ${ }^{9}$ Counsel for Mr Geys, on the other hand, argued in favoured of the elective theory on the basis that the decision in Gunton had given rise to no 'practical difficulty or injustice'. ${ }^{10}$

\section{Contextualising the facts}

The application of the automatic or elective theory of termination of contract would have produced two very different results for Mr Geys and the Bank. The effect of the automatic theory would be that the contract would have come to an end in November/December 2007 when the Bank committed the repudiatory breach by dismissing Mr. Geys. This would have entitled Mr Geys to a termination payment of no more than $€ 7 \mathrm{~m}$, inclusive of a contractual bonus payment. ${ }^{11} \mathrm{If}$, however, Mr Geys could choose to accept the Bank's repudiatory breach in January 2008 under the elective theory, he would be entitled to a termination payment of approximately $€ 12.5 \mathrm{~m}$ by virtue of a provision in his employment contract which would trigger the payment of a much higher bonus. Leaving aside the differing practical consequences of the application of the two theories, substantial theoretical and doctrinal arguments in each of their favour may be presented. ${ }^{12}$ For example, in the case of a repudiatory dismissal by the employer, the application of the elective theory at common law first and foremost provides the innocent employee with a choice whether (and when) to (i)

\footnotetext{
${ }^{9}$ [2012] UKSC 63; [2013] 2 WLR 50, 83G at [95] per Lord Wilson.

${ }^{10}$ ibid $100 \mathrm{C}$ at [100] per Lord Carnwath

${ }^{11}$ ibid 54C-E at [1] per Lord Hope.

12 These have been aptly discussed elsewhere and will only be briefly summarised here. See M.
} Freedland, The Personal Employment Contract (Oxford: Oxford University Press, 2003); J. McMullen, 'A synthesis of the mode of termination of contracts of employment' (1982) Cambridge Law Journal 110; D. Brodie, The Contract of Employment (Edinburgh: Thomson/W Green, Scottish Universities Law Institute, 2008) 197-199; and, D. Cabrelli and R. Zahn, 'The Elective and Automatic Theories of Termination at Common Law: Resolving the Conundrum' (2012) Industrial Law Journal 346. 
accept the employer's repudiatory breach and claim damages for constructive wrongful dismissal, or (ii) affirm the contract so that it continues in existence and/or seek damages. An identical line of reasoning grounded in the same notion of respect for the autonomy of the individual also applies where the employee has committed a wrongful resignation. In this manner, the elective theory establishes a principled framework applicable to the termination of the employment contract which accords with the general precepts of contract law ${ }^{13}$ and functions to 'accord [...] maximum protection to [the innocent party's] freedom of choice/autonomy'. ${ }^{14}$ The disadvantage of such an approach, however, is that it often fails to coincide with factual reality. Once there has been a repudiatory dismissal or resignation, the employment relationship is over and the employment contract is de facto at an end. As such, conferring a choice in favour of the employee in the context of a wrongful dismissal - or the employer where there has been a wrongful resignation - is positively artificial. Affording the innocent party the choice to terminate or affirm under the elective approach could have major financial implications - as in Mr Geys' case - but by no stretch of the imagination does it function to salvage the employment relationship.

Despite the fact that it goes against the grain of classic contractual principles, by making it clear that a repudiatory breach of the employment contract brings that relationship to an immediate end, the automatic theory, on the other hand, sits more comfortably not only with the practical realities of the employment relationship, but also with the common law principle that an employee cannot compel his employer to give him work, any more than an employer can compel an employee to work. Prior to Geys, the prevailing legal position ${ }^{15}$ sought to navigate a middle-ground between these two

\footnotetext{
${ }^{13}$ See K. R. Hadley, 'Exploring Election' (2006) 122 Law Quarterly Review 82, 83.

${ }^{14}$ E. Bant, 'Reconsidering the Role of Election in Rescission' (2012) 32 Oxford Journal of Legal Studies $467,480$.

${ }^{15}$ Gunton v Richmond-upon-Thames London Borough Council [1981] 1 Ch 448 and confirmed in Boyo v Lambeth London Borough Council [1994] ICR 727.
} 
theories by holding that an employee's acceptance of an employer's wrongful dismissal constituting a repudiatory breach of contract would be 'readily inferred' ${ }^{16}$ Thus, an employee would, in theory, be able to elect if and when to accept the repudiatory breach but in reality he would be deemed to have accepted it on its occurrence. Such an idea of inferred acceptance has rightly been criticised ${ }^{17}$ as it arguably places more weight on pragmatism than legal principle reflecting a notional, rather than actual prolongation of the employment relationship. Moreover, it is highly unsatisfactory from a doctrinal point of view as it muddies the waters between the two theories of termination and fails to provide for legal certainty. Thus, in applying Gunton in Mr Geys' case, the High Court found that Mr Geys had been dismissed in January 2008 whereas, adopting the same line of jurisprudence, the Court of Appeal ruled that his dismissal had taken place in December 2007.

\section{The Judgment}

Lords Wilson and Sumption delivered the main judgments in Geys; both addressed whether a repudiatory dismissal or resignation must be accepted by the innocent party in order to bring the contract of employment to an end. By a majority of four to one, the Supreme Court followed Lord Wilson's arguments in holding that the elective theory should be preferred. Lord Wilson's starting point was to consider the overall effect of the automatic theory as being 'to reward the wrongful repudiator of a contract of employment with a date of termination which he has chosen, no doubt as being, in the light of the terms of the contract, most beneficial to him and, correspondingly, most detrimental to the other, innocent, party to it. ${ }^{18}$ Lord Hope, in agreeing with Lord Wilson invoked the

\footnotetext{
${ }^{16}$ Gunton v Richmond-upon-Thames London Borough Council [1981] 1 Ch 448, 469A per Buckley L.

${ }^{17}$ See Gibson LJ in Boyo at 743 and D. Brodie n 12 above, at [18.10].

${ }^{18}$ [2013] 2 WLR 50. 73F at [66].
} 
consideration of 'manifest justice' ${ }^{19}$ citing the underlying principle that no person ought to be able to profit from their own wrong: ${ }^{20}$

The essential difference between the two theories may be said to be that under the automatic theory the decision as to whether the contract is at an end is made beyond the control of the innocent party in all circumstances, whereas under the elective theory it is for the innocent party to judge whether it is in his interests to keep the contract alive. ${ }^{21}$

This notion of 'justice' also appeared in Lord Carnwath's brief discussion of the issue ${ }^{22}$ while Lady Hale posited that 'the automatic theory simply cannot work in cases of repudiatory breach which do not amount to express dismissal or resignation [and] distinguishing between the two types of repudiation is both impracticable and unprincipled. ${ }^{23}$

However, before reaching the view that the above considerations led inescapably to the conclusion that the elective theory must prevail, Lord Wilson took the Court through the rather brief development of the automatic theory ending with the Sanders ${ }^{24}$ case. In Sanders, it was decided that 'a servant cannot sue for wages if he has not rendered services, and the wrongful dismissal prevents him rendering services' ${ }^{25}$ This was held to imply that 'the repudiation of a contract of employment is an exception to the general rule [that the elective theory applies on the repudiatory breach of the contract] ${ }^{26}$ and that the automatic theory must thus apply. Lord Wilson however concluded that 'the

\footnotetext{
19 ibid 61B at [19].

${ }^{20}$ ibid 59H at [15]. See also 60G at [18] per Lord Hope.

${ }^{21}$ ibid $61 \mathrm{~B}$ at [19].

22 ibid 85B-E at [100].

${ }^{23}$ ibid 61D-F at [42].

${ }^{24}$ Sanders v Ernest A Neale Ltd [1974] ICR 565.

${ }^{25}$ ibid 570-571 per Sir John Donaldson.

${ }^{26}$ ibid 571 per Sir John Donaldson.
} 
Sanders case was the only ordinary employment case in which the automatic theory was part of the basis of the decision [...] if, [...], it was in that sense the high-water mark of the automatic theory, it was scarcely the result of a flood tide. ${ }^{\prime 27}$ This, in turn, led him neatly on to address the often invoked debate surrounding the relationship between rights and remedies as a justification for the preference of the automatic theory. It has been pointed out elsewhere that the restrained attitude of the common law to a dismissed employee's remedies at common law has had a disproportionate impact on the rights afforded to an employee when the employer is in repudiatory breach of contract. ${ }^{28}$ For example, the orthodox approach of the judiciary is to constrain the scope for injunctive relief and orders of specific performance in the case of the employment contract. ${ }^{29}$ Ewing describes the debate in the following terms:

So the rights of the parties are to be driven and determined by the availability of remedies; the contract is automatically terminated by the unilateral repudiation of either party, simply because it is not capable of specific performance. As such the argument is hopelessly circular. $^{30}$

It is to be welcomed that Lord Wilson disapproved of this circular argument which he dismissed by citing Ewing's description of the automatic theory as 'a bastard doctrine, which is difficult to

\footnotetext{
${ }^{27}$ [2013] 2 WLR 50, 80F at [89].
}

28 J. McMullen, 'A synthesis of the mode of termination of contracts of employment' (1982) Cambridge Law Journal 110, 122-123 and D. Cabrelli and R. Zahn, 'The Elective and Automatic Theories of Termination at Common Law: resolving the conundrum?' (2012) Industrial Law Journal $346,349-351$.

${ }^{29}$ L. Barmes, 'Remedying Workplace Harassment' (2002) 55 Current Legal Problems 347, 354-364.

${ }^{30}$ K. Ewing, 'Remedies for Breach of the Contract of Employment' (1993) Cambridge Law Journal 405, 410-411. 
reconcile with the general principles of contract law. ${ }^{31}$ As such, Lord Wilson's judgment follows the same approach as Scots law whereby the content and nature of the right tends to dictate the remedy. This mode of analysis in Scots law is complemented by the absence of any presumption against injunctive relief which can be adopted in support of the automatic theory. ${ }^{32}$

Having discussed the relationship between rights and remedies, Lord Wilson proceeded to an analysis of the Court of Appeal's much discussed decision in Gunton. As Lord Hope pointed out earlier in Geys in his endorsement of Lord Wilson's arguments:

One must be careful not to assume that, just because in practice the employee may have little choice but to accept the repudiation, he has in law no alternative but to do so. ... If the law requires acceptance of the repudiation, the requirement is for a real acceptance - a conscious intention to bring the contract to an end, or the doing of something that is inconsistent with its continuation. ${ }^{33}$

Lord Wilson agreed with such criticisms of the Court of Appeal's diluted approach of the notion of a 'readily inferred acceptance' in Gunton and it seems clear that any future application of the elective theory following Geys gives the innocent party a real choice of when to accept the repudiatory breach of contract.

In the final paragraphs of his judgment, Lord Wilson returned to the automatic theory and posed a number of questions which he suggested ought to be answered in order to explain how it could possibly apply, but did not expand upon or respond to these questions. One of the most significant observations made by Lord Wilson was that the automatic theory would force the court to devise

\footnotetext{
${ }^{31}$ [2013] 2 WLR 50, 81A-B at [89] citing K. Ewing, 'Remedies for Breach of the Contract of Employment' (1993) Cambridge Law Journal 405, 415.

${ }^{32}$ Brodie, n 12 above, 197.

${ }^{33}$ [2013] 2 WLR 50, 60F at [17].
} 
criteria to distinguish between different classes of repudiatory breach: those consisting of an express dismissal or resignation would attract the application of the automatic theory, whereas the elective approach would apply in all other cases. As a matter of principle or practice, Lord Wilson was not convinced that this was a logically sustainable or practicable approach ${ }^{34}$ Lord Wilson then finished by dismissing the Bank's argument in favour of the automatic theory in the following terms:

In proposing that the court should indorse the automatic theory, the Bank invites it to cause the law of England and Wales in relation to contracts of employment to set sail, unaccompanied, upon a journey for which I can discern no just purpose and can identify no final destination. I consider, on the contrary, that we should keep the contract of employment firmly within the harbour which the common law has solidly constructed for the entire fleet of contracts in order to protect the innocent party, as far as practicable, from the consequences of the other's breach. ${ }^{35}$

\section{E. The dissenting judgment}

Lord Sumption, in a compelling judgment, disagreed with Lord Wilson, arguing first that the case law relied upon in favour of the elective theory is much more nuanced than appears from his reasoning. He suggested that:

The expression [of the 'elective theory'] is [...] misleading because it suggests that the innocent party's right to treat the contract as subsisting necessarily flows from the unilateral character of the other party's repudiation. In fact, the right to treat the contract as subsisting has never been absolute. It is subject to important exceptions and qualifications. ${ }^{36}$

\footnotetext{
${ }^{34}$ ibid 84B-D at [94].

35 ibid $84 \mathrm{G}$ at [97].

${ }^{36}$ ibid $88 \mathrm{E}-\mathrm{F}$ at [114]. His Lordship then goes on to refer to the summary of case law given by Lord Reid in White \& Carter (Councils) Ltd v McGregor [1962] AC 413.
} 
Thus, 'the purpose of the right to treat a repudiated contract as subsisting is to enable it to be performed at the option of the innocent party' ${ }^{\prime}{ }^{37}$ However, when a contract cannot be performed or enforced, - as is frequently the case in the context of employment contracts where specific performance is not available $-{ }^{38}$ Lord Sumption found it 'difficult to see why the law should recognise such a right [as is granted by the elective theory]. ${ }^{\prime 39}$ Moreover, agreeing with Shaw L's reasoning that 'the continued vestigial existence of an unperformable contract was an artificial fiction devoid of any connection with the true state of affairs', ${ }^{40}$ Lord Sumption suggested that Gunton was 'wrongly decided'41. His Lordship disagreed with Mr. Geys's argument that Gunton had given rise to no difficulty or injustice in the thirty years since it was decided, recalling instead that Gunton had long been a controversial decision of a divided court the application of which 'would give rise to significant injustice in this case. ${ }^{, 42}$ Lord Sumption also disagreed with the weight placed on 'manifest justice' as an argument in favour of the elective over the automatic theory. He suggested

\footnotetext{
37 ibid 89D at [116].

${ }^{38}$ See De Francesco v Barnum (1890) 45 Ch D 430, 438 (Fry L), Ridge v Baldwin [1964] AC 40, 65 per
} Lord Reid and Wilson v St. Helen's Borough Council [1999] 2 AC 52, 84A-B per Lord Slynn of Hadley.

${ }^{39}[2013] 2$ WLR 50, 89E at [116].

40 ibid $100 \mathrm{D}$ at [138].

${ }^{41}$ ibid $100 \mathrm{G}$ at [139].

${ }^{42}$ ibid $102 \mathrm{H}$ at [140]. The injustice that Lord Sumption refers to is explained at [2013] 2 WLR 50, 87F-

$\mathrm{H}$ at [110] of his judgment: 'Although the employment relationship was dead for all practical purposes from 29 November, and Mr Geys contributed nothing to SG's fortunes after that date, he is in a position to argue that technically the contract limped on as a formal 'shell' or 'husk' (to use the terms deployed in argument) into January 2008. The financial consequences of this, if it is right, are considerable. [...] The figures are disputed, but the result is likely to be that SG's breach, although it has caused Mr Geys no substantial loss, will have brought him a windfall amounting to several million euros. Rarely can form have triumphed so completely over substance.' 
that 'it is no part of the purpose of the law to reflect moral indignation about [the Bank's] conduct' ${ }^{43}$ Moreover, the value of an argument based on 'manifest justice' is limited as provided the employer adheres to the correct procedure when terminating a contract of employment, it may terminate it at a time of its own choice. In such a case, the decision as to whether the contract is at an end 'is made beyond the control of the innocent party ${ }^{\prime 44}$ thus affording no greater protection than the automatic theory. On that basis therefore, Lord Sumption suggested that 'it is always dangerous to allow the law to part company with reality [as occurs with the elective theory]' as 'it leads to unexpected and highly technical results. ${ }^{45}$

Lord Sumption's arguments, however, did not find favour with the majority of the court. Accordingly, the elective theory applies in all cases of a repudiatory breach of the contract of employment, including wrongful dismissals and resignations, and 'doctrinal purity'46 across the entire breadth of contract law has been restored. Does this mean then that the law relating to the termination of the contract of employment has been clarified once and for all? Interestingly, Lord Wilson briefly raises the issue of the unavailability of specific performance as a remedy. He recognises it as 'one of the great unresolved questions of employment law. ${ }^{47}$ However, he goes on to point out that 'even if the question can be said to be unresolved, this court is not invited to resolve it. ${ }^{48}$ While the contract of employment thus no longer deviates from contractual principles when it comes to repudiatory breach, it remains a special case in terms of remedies.

\footnotetext{
${ }^{43}$ ibid $103 B$ at [140].

${ }^{44}$ See Lord Hope ibid 61B at [19].

${ }^{45}$ ibid $103 B$ at [140].

${ }^{46}$ ibid 102E at [140] per Lord Sumption.

${ }^{47}$ ibid 77C at [79] citing Sedley L in Cerberus Software Ltd v Rowley [2001] ICR 376, 386.

${ }^{48}$ ibid 77D at [79].
} 


\section{F. Analysis}

The analysis of the majority of the Supreme Court can be approached from two angles: the first operates at an abstract level, considering the implications of Geys for the innate nature of the common law of the employment contract, whereas the second line of enquiry is constructed along doctrinal lines, focussing attention on the impact of Geys on the internal coherence of the law.

\section{Geys in context}

The Supreme Court's adoption of the elective theory in Geys can be examined in light of its jurisprudence in a series of recent cases relating to the common law of the contract of employment: Gisda Cyf v Barratt, ${ }^{49}$ Autoclenz Ltd. v Belcher ${ }^{50}$ and Edwards v Chesterfield Royal Hospital NHS Foundation Trust. ${ }^{51}$ Together with Geys, this quartet can be explored on the basis of whether the Supreme Court (i) adopted orthodox contractual principles or (ii) preferred the interests of labour over the managerial prerogative.

If we begin with Geys, the fact that the Supreme Court applied general principles of contract law in the context of the common law of the contract of employment might lead us to the conclusion that the courts are committed to adopting rules and principles which ensure that the employment contract is nothing special so that it is treated the same as any other contract, without exception. For example, noting that the elective theory applied in other areas of contract law, such as wrongful terminations of the contract for services, Lord Wilson referred to the absurdity of the suggestion that a chasm should be opened up in contract law by the adoption of the automatic theory of termination in the common law of the contract of employment..$^{52}$ However, as compellingly argued by Bogg, ${ }^{53}$

\footnotetext{
${ }^{49}$ [2010] UKSC 41; [2010] 4 All ER 851.

${ }^{50}$ [2011] UKSC 41; [2011] 4 All ER 745.

${ }^{51}$ [2011] UKSC 58; [2012] 2 AC 22.

52 [2012] UKSC 63; [2013] 2 WLR 50, 84F at [96] per Lord Wilson.
} 
rationalising the mind-set of the courts as one which is predominantly concerned with the unity of contract law and the denial of the doctrinal autonomy of the common law of the contract of employment would be wide of the mark in the contemporary context: in each of Gisda Cyf ${ }^{54}$ and Edwards ${ }^{55}$ the Supreme Court departed from conventional contract law doctrine in order to respond to the particularities of the employment relationship. For example, in Gisda Cyf, the Supreme Court declined to follow contractual principles and held that when an employer sought to accept an employee's repudiatory breach of contract and summarily dismiss the employee, the effective date of termination was not until the employee had actually read the communication or had had a reasonable opportunity of reading it. This approach is unlike general contract law where a termination occurs $s_{2}$ for the purposes of the statutory unfair dismissal regime in Part $\mathrm{X}$ of the Employment Rights Act 1996 ('ERA'), when an employer has done all that could reasonably be required of him to communicate his decision to accept the employee's repudiation of the contract of employment, for the purposes of the statutory unfair dismissal regime in Part $X$ of the Employment Rights Act 1996 ('ERA'), the effective date of termination was not until the employee had actually read the communication or had had a reasonable opportunity of reading it. ${ }^{56}$ Likewise, Edwards $^{57}$ concerned the remedies available to an employee where an express term of the employment

${ }^{53}$ See A. Bogg, 'Sham Self-Employment in the Supreme Court' (2012) 41 Industrial Law Journal 328, 331-332.

${ }^{54}$ [2010] UKSC 41; [2010] 4 All ER 851.

55 [2011] UKSC 58; [2012] 2 AC 22.

${ }^{56}$ See J. Prassl, "Interpreting Employment Protective Legislation: Gisda Cyf v Barratt" (2011) 40 Industrial Law Journal 103.

${ }^{57}$ See H. Collins, "Compensation for Dismissal: In Search of Principle" (2012) 41 Industrial Law Journal 208 and K. Costello, "Edwards v Chesterfield Royal Hospital - Parliamentary Intention and Damages Caused by Maladministration of a Contractual Dismissal Procedure" (2013) 76 Modern Law Review 134. 
contract providing for managerial adherence to a disciplinary procedure had been breached. In a radical deviation from convention, the Supreme Court ruled that damages were not recoverable by an employee for a breach of such an express term since theyit related to the manner of the employee's dismissal. Instead, the 'curious' ${ }^{58}$ result was that an injunction was the primary remedy available to enforce a contractual disciplinary procedure. This serves to remind us of the fact that the courts are not necessarily wedded to an approach which unflinchingly clings to contractual principles, but will depart from, or puncture, them to create exceptions for the contract of employment in certain circumstances. In some of those cases, this was done to reflect the unique character of the employment contract ${ }^{59}$ and in other cases, it was motivated by a desire not to undermine the operation of statutory employment protection legislation. ${ }^{60}$ However, Gisda Cyf and Edwards can be contrasted with Autoclenz, ${ }^{61}$ where the judiciary followed an altogether different path. Here, the Supreme Court adapted the common law 'sham' doctrine ${ }^{62}$ to uphold the argument that the relative bargaining power of the employer and employee must be considered in deciding whether the terms of the written employment contract actually represented what had been agreed. By applying a contextual construction of the contract of employment and deciding that the true agreement between the parties will often have to be gleaned from all the circumstances of the case, of which

${ }^{58}$ [2011] UKSC 58; [2012] 2 AC 22, 71A at para [154] per Lord Kerr.

${ }^{59}$ Autoclenz and Edwards.

${ }^{60}$ Gisda Cyf and Edwards.

${ }^{61}$ [2011] UKSC 41; [2011] 4 All ER 745. See A. Bogg, "Sham Self-Employment in the Supreme Court" (2012) 41 Industrial Law Journal 328 and J. McClelland, "A Purposive approach to Employment Protection or a Missed Opportunity?" (2012) 75 Modern Law Review 427.

${ }^{62}$ See Snook v London and West Riding Investments Ltd [1967] 1 All ER 518, [1967] 2 QB

786, [1967] 2 WLR 1020 
the written agreement is only a part, it is arguable that the formulation of the Supreme Court is reconcilable with ordinary principles of the contractual law of interpretation. ${ }^{63}$

Of course, the question arises as to why the courts sometimes apply contractual principle, occasionally modify it, and in other cases plainly abandon it. That question is closely aligned to the issue of the wider effect of Geys on employment law as an autonomous discipline. Ultimately, the contemporary judicial recognition of a conception of employment that transcends simple economic transactions and exchanges to reflect the social reality of subordination in the relationship ${ }^{64}$ gives rise to powerful policy considerations which dictate whether contractual orthodoxy ought to be adhered to or discarded. The realisation that legal doctrine and precedent must give way to policy in employment law ${ }^{65}$ in certain circumstances is laid bare in the somewhat revealing dissenting judgment of Lord Sumption in Geys:

'Subject to the intervention of statute, contracts of employment are governed by the same principles as other contracts, except in those cases where their subject matter gives rise to compelling policy considerations calling for a different approach. But the relationship of employer and employee is especially liable to give rise to policy considerations of this kind, because its incidents have significant social and economic implications. They affect a high proportion of the adult population and have a profound impact both on their personal lives and on their relationships with others... the relationship of employer and employee was traditionally regarded as a highly personal one. In an age of large corporate enterprises many of whose employees perform routine jobs, the personal character which was once typical of employment relationships has lost much of its former importance. But employment is none

\footnotetext{
${ }^{63}$ See the persuasive analysis in A. Bogg, "Sham Self-Employment in the Supreme Court" (2012) 41 Industrial Law Journal 328, 336-343.

${ }^{64}$ See also H. Collins, 'Notes. Claims for Unfair Dismissal' (2001) 30 Industrial Law Journal 305.

${ }^{65}$ See also the discussion in Bogg n 53 above, 331-332.
} 
the less a relationship based on mutual trust and confidence, a factor which has assumed growing importance in the way that the law has developed over the past 30 years.... legal thinking in this area has always been influenced by a concern for the productive use of resources, including labour. This is evident in the development of the common law relating, for example, to restrictive covenants and, at a more macro-economic level, to the economic torts of interference with contractual relations and procuring a breach of contract and aspects of the law of conspiracy. It is reflected in the abiding concern of the common law to ensure the terminability of contracts of employment, without prejudice to the subsequent regulation of the financial consequences by an award of damages. The harsher consequences of this approach for individuals have been mitigated in the last half century by a parallel scheme of statutory protection of employment, operating within defined limits and administered by specialised statutory tribunals with limited jurisdiction over purely contractual disputes. ${ }^{166}$

Although it is undoubtedly true to say that the policy objectives underpinning various rules of the common law of the contract of employment can be modified by the judiciary and have indeed advanced in a socially progressive manner in recent times, ${ }^{67}$ e.g. by analogy with the growth in statutory employment protection ${ }^{68}$ and in response to de-collectivisation and de-unionisation, 'deregulation of the labour market, the privatisation of public services, and the globalisation of product and financial markets', ${ }^{69}$ Lord Sumption reminds us in Geys that it is inaccurate to

\footnotetext{
${ }^{66}$ [2013] 2 WLR 50, 90E-91D at [118]-[119] per Lord Sumption.

${ }^{67}$ L. Barmes, 'The Continuing Conceptual Crisis in the Common Law of the Contract of Employment' (2004) 67 Modern Law Review 435, 451.
}

${ }^{68}$ Johnson v Unisys Ltd. [2003] 1 A.C. 518, 539 C at para. 37 per Lord Hoffmann. See also Eastwood v Magnox Electric plc [2005] 1 A.C. 503, 524 at paras. 12-14 per Lord Nicholls and M. Freedland, The Personal Employment Contract (OUP, 2003) 339-344.

${ }^{69}$ Johnson v Unisys Ltd. [2003] 1 A.C. 518, 539D at para. 19 per Lord Steyn. 
characterise the common law as a primary sources of norms in the workplace operating exclusively in a worker-friendly direction. ${ }^{70}$ Sometimes, as in $E d w a r d s^{71}$, the compelling policy issues identified in a particular case by the court will be contrary to the interests of labour whereas in others, such as Autoclenz, Gisda Cyf and Geys, they will not. Ultimately, the issue is one of balancing competing interests.

In Geys, the Supreme Court placed a great deal of emphasis on justice and party autonomy as the grounds for its decision in favour of the employee. However, one must not underestimate the power of policy preferences based on certainty and practicability or on considerations of acting in a way which does not frustrate parliamentary intention. Yet while policy issues will vary, a clearer picture as to the orientation of a doctrinally independent common law of the contract of employment is bound to eventually emerge. ${ }^{72}$

\section{Doctrinal effect of Geys}

Not only does Geys provide an insight into the prevailing attitude of the courts to the direction of the development of the common law of the employment contract, it also has importance for our understanding of the doctrinal framework of that contract. Here we pursue the implications of a number of more radical lines of development in doctrine opened up by Geys. First, we will explore the point made in Geys that the elective theory also applies to express resignations. Second, we will address the impact of the theory on summary dismissals. Finally, we will consider the elective

\footnotetext{
${ }^{70}$ [2013] 2 WLR 50, 91D-91E at [119] per Lord Sumption.

${ }^{71}$ Which Collins describes as a case where the courts made 'a brute policy choice designed to subvert the contractual rights of employees'. See H. Collins, 'Compensation for Dismissal: In Search of Principle' (2012) 41 Industrial Law Journal 208, 226.

${ }^{72}$ See A. Bogg, 'Sham Self-Employment in the Supreme Court' (2012) 41 Industrial Law Journal 328, 344.
} 
theory's interaction with the mutuality principle in Scots law and the traditional hostility of the common law courts to the awarding of orders of specific performance.

First, Geys explicitly applies the elective theory to wrongful resignations. In such a context, one might think that its application is an affront to the principle of liberty so intrinsic to common law jurisprudence, ${ }^{73}$ as well as being impractical and unlawful, ${ }^{74}$ since it would appear to enable an employer to coerce an employee to continue working against his will. However, this objection is illusory for two reasons. First, common law rules designed ${ }^{75}$ to prevent a contracting party from forcing unwanted performance on the counterparty and then claiming payment could be adapted to limit some of the more oppressive aspects of the elective theory. ${ }^{76}$ Second, statutory inroads into the common law have been made by section 236 of TULR(C)A which precludes an employer from obtaining injunctive relief or an order of specific performance compelling the employee to do any work or attend at any place for the doing of any work. As such, faced by a wrongful resignation, the most that an employer could do is compel the employee to take garden leave for the period of his contractual notice period, which may give rise to the judicial recognition of an implied term empowering employers to put employees on garden leave in the absence of a power to do so

${ }^{73}$ See Nokes v Doncaster Amalgamated Collieries Ltd. [1940] AC 1014, 1020 per Viscount Simon (LC) and 1033 per Lord Atkin.

${ }^{74}$ See section 236 of the Trade Union and Labour Relations (Consolidation) Act 1992 ('TULR(C)A').

${ }^{75}$ See the rules developed as exceptions to White and Carter (Councils) Ltd v McGregor [1962] AC 413.

${ }^{76}$ See Attica Sea Carriers Corp v Ferrostaal etc. [1976] 1 Lloyd's Rep. 250 and The Alaskan Trader [1984] 1 All ER 129. For example, where the employer no longer has any legitimate interest in the performance of the contract subsequent to the employee's wrongful resignation, the court has the power to exercise its general equitable jurisdiction and refuse to permit the employer to insist on its strict legal rights. 
pursuant to an express term. ${ }^{77}$ During that period, the employee will continue to be bound by obligations of mutual trust and confidence pursuant to the implied terms of the employment contract, albeit that he cannot be forced to perform work against his will.

As for the impact of the elective theory on the law of repudiatory breach and termination of the contract of employment, two key issues arise. The first is generic in nature, but the second pertains specifically to Scots law. First, the elective theory has serious implications for the law of summary dismissal. Consider the situation where the employee is caught stealing by the employer and the employer summarily dismisses the employee without notice on the ground of gross misconduct, i.e. that the employee has committed a repudiatory breach. The employee then responds by refuting the employer's contention that he is guilty of gross misconduct, claims that the employer's summary dismissal is itself a repudiatory breach and affirms the contract of employment without delay. The question which arises is whether the employer should pay lost wages as a debt from the moment of the employee's affirmation, together with contractual damages for its failure to provide the requisite notice. The difficulty that the employer has is that it will not know whether the summary dismissal was valid on the basis of the employee's gross misconduct until an employment tribunal or court declares it to be so some time later. In the meantime, the employer is left in the unenviable position of deciding whether (i) to take its chances on the tribunal or court subsequently finding that the summary dismissal was valid and refuse to pay the employee notice damages and lost pay or (ii) pay the employee notice damages and lost pay whilst reserving its position and then go to court to recover this sum on the basis that the employee was guilty of gross misconduct and the summary dismissal was valid. This strikes the writers as a somewhat contrived dynamic, which opens up a degree of peril for employers.

${ }^{77}$ Cf. William Hill Organisation Ltd v. Tucker [1999] ICR 291, 301F per Lord Justice Morritt. 
Turning now to the consequences of the elective theory in the context of Scots law, one issue which emerges is its relationship with the 'mutuality of breach' doctrine. The mutuality doctrine provides that where an employer is in repudiatory breach of contract, the employee cannot claim damages for breach of contract or accept the employer's breach as a means of terminating the contract at common law or claiming constructive dismissal under section 95(1) of the ERA, if he/she had committed an anterior repudiatory breach of contract. ${ }^{78}$ By the same token, where the employee is in repudiatory breach of contract, the employer is precluded from claiming damages for breach of contract or invoking the employee's repudiatory breach as a means of terminating the employment contract, if the employer was guilty of having committed a prior repudiatory contractual breach. As noted by Collins, ${ }^{79}$ this doctrine is one which is alien to English law, but applies in Scots law as a result of its inherent emphasis on the enforcement of performance as the primary remedy open to a party confronted with a material breach by the counterparty. Since the mutuality principle deprives a contracting party $A$ in anterior repudiatory breach of the choice whether to accept counterparty $\mathrm{B}^{\prime} \mathrm{s}$ repudiatory breach and bring the contract to an end or claim constructive dismissal under section 95(1)(c) of the ERA, it is generally inconsistent with the elective theory. As such, any meaningful election by party $A$ is precluded and in a certain sense, he is readily inferred to have affirmed the contract of employment in response to counterparty B's repudiatory breach. Accordingly, the elective theory of termination is inconsistent with the mechanics of, and must give way to, the mutuality principle, which represents a clear exception to the approach sanctioned by the majority of the Supreme Court in Geys.

\section{G. Conclusion}

\footnotetext{
${ }^{78}$ Aberdeen City Council v McNeill [2010] IRLR 374.

${ }^{79} \mathrm{H}$. Collins, 'Constructive Dismissal and the West Lothian Question: Aberdeen City Council v McNeill (2011) 40 Industrial Law Journal 439.
} 
The decision in Geys is to be welcomed as clarifying an area of the common law that has long been in a state of disarray. From a doctrinal point of view, the Supreme Court has provided a clear framework applicable to instances of wrongful termination of the employment contract. The decision provides support for the recognition of the common law rule that the consideration for wages is the readiness and willingness of an employee to work rather than the rendering of the work/service itself. ${ }^{80}$ This means that the absence of the latter is not an impediment to the ability of an employee to affirm the contract and demand work or lost wages as a debt for the failure of the employer to provide work, notwithstanding the destruction of the employment relationship. It also confirms the common law rule that there is an implied duty to pay wages where the employee undertakes no work in the case of illness ${ }^{81}$ or lay-off..$^{82}$ However, what Geys does not resolve is whether 'the more impersonal, less hierarchical, relationship of many employers with their employees requires review of the usual unavailability of specific performance [in the common law] ${ }^{83}$ Lord Wilson left the issue open for future consideration and Lord Sumption did not address it. Thus, while Geys resolves the conundrum surrounding the applicability of the automatic versus the elective theories of termination, it fails to provide a resolution of the debates surrounding the range of remedies available for a breach of the employment contract. The identification of a normatively sound framework that addresses these conceptual difficulties arising in relation to the common law remedies for a breach of the contract of employment has therefore been deferred to a later date.

\footnotetext{
${ }^{80}$ See Cuckson v Stones (1858) 1 E \& E 248, Miles v Wakefield [1987] AC 539, 561A-B and 564G-565B per Lord Templeman, Miller v Hamworthy Engineering Ltd. [1986] IRLR 461, BT v Ticehurst [1992] ICR 383 and Beveridge v KLM (UK) Ltd. [2000] IRLR 765, 766 per Johnston J.

${ }^{81}$ See Cuckson v Stones (1858) 1 E \& E 248 and Marrison v Bell [1939] 2 KB 187. However, cf. O'Grady v Saper [1940] 2 KB 469 and Mears v Safecar Security Ltd. [1983] Q.B. 54.

${ }^{82}$ Bond v Cav Co. [1983] IRLR 360; Devonald v Rosser (1906) 2 KB 728.

${ }^{83}$ [2012] UKSC 63; [2013] 2 WLR 50, 76G at [77] per Lord Wilson.
} 
Word count including footnotes: 6848

Word count excluding footnotes: 5518 